\title{
Learning with Technology: New Experiences for Indonesian Children During COVID-19
}

\author{
Muassomah Muassomah,,$^{1 *}$ Irwan Abdullah ${ }^{2}$ \\ ${ }^{1}$ Universitas Islam Negeri Maulana Malik Ibrahim Malang, Indonesia \\ ${ }^{2}$ Universitas Gajah Mada Yogyakarta, Indonesia \\ *Corresponding author.Email: muassomah@bsa.uin-malang.ac.id
}

\begin{abstract}
Technology, which was previously considered a negative influence on children, has turned out to be the only solution for the education sector during the Covid-19 pandemic. The education system has experienced a shift from face-toface learning at school to technology-based home learning as a result of social and physical distancing policies implementation. This study aims to describe the experience of elementary school children during online learning without the presence of professional teachers and peer community who can instigate their competitive spirit. This paper describes the parents' difficulties and obstacles as they are demanded to substitute the role of professional teachers for their children. A qualitative descriptive approach is applied in this study with offline and online interview techniques as data collection instruments. The data were collected from elementary school children with different backgrounds to explore their experiences of online learning. This paper focuses on the perspective of children in learning online during the pandemic in several schools in one city, as well as the experiences of their parents who are demanded to become teachers. This study concludes that technology, which is a prerequisite for online learning, actually creates hindrance for children. Children are stressed, refuse to study, lose enthusiasm for learning, and lose structured time dimension. All of those are because they learn individually and not communally. Further research is needed to explore the perceptions of students at different levels of education during the pandemic.
\end{abstract}

\section{Keywords: Online Learning, Learning Technologization, Technology Literacy, Elementary School Students}

\section{INTRODUCTION}

Communication media such as android and the internet, which were previously thought to have a negative impact and should be kept away from students, are now greatly needed and become primary needs for students [1]. The COVID-19 pandemic has brought an enormous impact on all aspects of human life throughout the world, including Indonesia. To suppress the virus transmission, the government is imposing lockdown and social distancing policies which then affect the education sector, including elementary schools learning. The educational process that has been carried out face to face between teachers and students at schools has to shift to online learning at home with the help of technology. The transfer of knowledge has changed from teacher explanations to assignments, individual reading, and practice questions. As a result, the students only obtain the basics of the information that was previously provided in detail and through direct experience and concrete examples. Technology is the main requirement for online learning, thus technological tools are permitted for children to use.

The previous researches have shown that educational technology is viewed in terms of its utilization to enrich skills and expand knowledge [2], [3]. Technology as a learning medium can facilitate the delivery of materials to students [4]-[6]. Therefore, technology-based learning must pay attention to three very crucial components, namely hardware, software and human resources (brainware) [7]. Another study confirms that educational technology requires smart and skillful human resources [8]-[10]. In addition, 
educational technology requires the adjustment of learning devices, such as curriculum, syllabus, learning designs, and many others so that the students' knowledge is profound and the values they learn can be internalized [11]. Technological challenges in education change human activities, especially teachers and students, in terms of their scale, scope, complexity, and transformation from previous life experiences [12], [13].

This paper aims to show that the Covid-19 outbreak has caused elementary school children to study independently without teachers and friends collectively present in the learning process. The sudden change of education system from school-based to home-based has disarrayed the previously neatly structured learning process. It affects all education members and stakeholders, especially children (students) and parents. To provide a detailed description, this research addresses three points: 1) Students' learning experience at home, such as their stress, refusal to study, and low literacy levels; 2) Struggles and difficulties of parents while accompanying their children to study at home, and how the solutions are implemented; 3 ) The meaning and effect of those changes for the purpose/mission of education.

This paper argues that the shift in the education system from conventional to virtual/technological caused by Covid-19 causes not only various concern in the education sector, including children, parents, and educational missions, but also a force that transforms the education system and encourages the shift of children position from objectification to subjectification. Children have the freedom to set their own study schedule. They also have the opportunity to learn effectively, being able to continue the subject matter without having to wait for their friends. On the other hand, children who are slower to understand lesson can repeat it without worrying about being left behind by other children. Online learning requires new technology, behavior and thinking skills to be carried out and completed successfully [14].

\section{METHOD}

This research was conducted using a qualitative descriptive method which focuses on describing children's experience in undergoing new learning system, the online learning that was previously done face to face. The focus of this research is on elementary schools in Malang city, Indonesia. Elementary schools were chosen because the students' ages are around 6-12 years old. Children at this age are still very dependent on professional teachers and peer communities, but in this situation, they are forced to undertake distance learning. As many as 12 elementary schools affiliated with Islam in the city area were taken as sample of this study. The participants include 20 elementary school students and their parents as companions to the learning process at home. In addition to the students, the parents are also the focus of this study.

Data in the form of children's experiences were heard using online interviews via video calls, Google Meet, and Zoom. This method was done to adhere to the social and physical distancing policies that do not allow face to face interviews. Likewise, the experiences of parents while assisting their children studying at home, who were previously assisted by teachers at school, were explored. This new task has brough about struggle and difficulties for parents. Texts on national education goals are also needed as information/data to complement this paper.

The data were collected through observation on the learning process of the researcher's several close relatives. The learning activities at home were observed starting from when the children wake up until they sleep again, and the research also focuses on the role and assistance of parents for their children. Interviews were conducted to explore the children's and parents' experiences of online learning system. Documentation is also needed to understand the mission and purpose of national education.

The data collected were analyzed according to the stages of qualitative descriptive research, which includes data reduction, data display, and conclusion drawing. Data reduction was carried out by selecting data that were relevant to the research topic, as well as sorting out data that were less supporting. Next, the data were arranged in tables to simplify and clarify its presentation. The data were then given a brief description to further explain the information. Prior to drawing conclusions, the data were interpreted by providing its definition and meaning of existing information. Innovation and creativity of data interpretation were carried out to determine the meaning behind the data collected while ensuring their originality.

\section{RESULT AND DISCUSSION}

\subsection{Students' Experiences of Online Learning}

Covid-19 has changed the learning system at various levels of education in Indonesia, from conventional to digital teaching and learning. This shift is a new experience for education in Indonesia, especially for elementary educational institutions. Children, who are directly affected by the government policies in preventing the transmission and spread of Covid-19, have had experiences that we cannot ignore, including becoming stressed, feeling bored, and lacking learning enthusiasm; refusing to study because of distractions and temptations during the process; and the low level of technological literacy. 
Table 1: Student experiences of online learning

\begin{tabular}{|c|c|c|}
\hline No. & Student experiences & Code \\
\hline 1 & $\begin{array}{l}\text { I am now allowed to use a } \\
\text { cellphone because the study } \\
\text { depends on it }\end{array}$ & $\begin{array}{l}\text { Technological } \\
\text { legality }\end{array}$ \\
\hline 2 & $\begin{array}{l}\text { Besides studying, I can use } \\
\text { the cellphone to play games } \\
\text { limitlessly }\end{array}$ & $\begin{array}{l}\text { Technology } \\
\text { utilization }\end{array}$ \\
\hline 3 & $\begin{array}{l}\text { I study using WhatsApp, } \\
\text { Quiziz or Zoom (I ask help } \\
\text { from my mother or older } \\
\text { sister/brother) }\end{array}$ & $\begin{array}{l}\text { Low technological } \\
\text { literacy }\end{array}$ \\
\hline 4 & $\begin{array}{l}\text { When I do not understand } \\
\text { how to do the tasks from my } \\
\text { teachers, I use Youtube, } \\
\text { Google, browsers, and } \\
\text { WPS. }\end{array}$ & $\begin{array}{l}\text { The disappearance } \\
\text { of teachers' } \\
\text { explanation }\end{array}$ \\
\hline 5 & $\begin{array}{l}\text { I do not really know how to } \\
\text { make use of the applications } \\
\text { which I need. }\end{array}$ & $\begin{array}{l}\text { Low technological } \\
\text { literacy }\end{array}$ \\
\hline 6 & I study less and play more & Low knowledge \\
\hline 7 & $\begin{array}{l}\text { I am bored because studying } \\
\text { at home means doing } \\
\text { monotonous activities }\end{array}$ & Monotony \\
\hline 8 & $\begin{array}{l}\text { Leaning online is boring } \\
\text { because I have no friends to } \\
\text { study with, play with, and } \\
\text { talk with }\end{array}$ & Monotony \\
\hline 9 & $\begin{array}{l}\text { No material explanation } \\
\text { from the teachers }\end{array}$ & $\begin{array}{l}\text { The disappearance } \\
\text { of teachers' } \\
\text { explanation }\end{array}$ \\
\hline 10 & $\begin{array}{l}\text { Many materials are difficult } \\
\text { to understand but the tasks } \\
\text { should be done right away }\end{array}$ & Without assistance \\
\hline 11 & $\begin{array}{l}\text { I cannot meet my teachers } \\
\text { and friends and we cannot } \\
\text { do activities together }\end{array}$ & $\begin{array}{l}\text { The loss of } \\
\text { community }\end{array}$ \\
\hline 12 & $\begin{array}{l}\text { Since there is no specific } \\
\text { time, I become more relaxed }\end{array}$ & $\begin{array}{l}\text { The loss of } \\
\text { discipline }\end{array}$ \\
\hline 13 & $\begin{array}{l}\text { I can study while lying } \\
\text { down }\end{array}$ & $\begin{array}{l}\text { The loss of } \\
\text { discipline }\end{array}$ \\
\hline 14 & $\begin{array}{l}\text { Sometimes I am lazy to } \\
\text { study, preferring to play } \\
\text { games on my cellphone }\end{array}$ & $\begin{array}{l}\text { The loss of } \\
\text { learning } \\
\text { enthusiasm }\end{array}$ \\
\hline 15 & $\begin{array}{l}\text { I can study in the living } \\
\text { room, in front of the TV, in } \\
\text { the bedroom, and I can } \\
\text { study while lying down, } \\
\text { eating, and playing }\end{array}$ & Flexibility \\
\hline
\end{tabular}

The closure of schools as a measure to anticipate the spread of Covid-19 requires a shift in the learning process from offline to online. The learning process, which was previously carried out at school with teachers and friends face to face, is now carried out at home with parents and family. It has caused stress for children because they only learnt by doing assignments from the teachers without understanding the materials. Besides, distance learning makes children bored as they only carry out activities around the house. Meanwhile, when studying at school, children get more and more varied learning experiences, such as learning in the classroom, on the school grounds, and in places related to the subjects, such as markets, zoo, agricultural and plantation institutions, libraries, and many others. Online learning also diminishes the motivation to learn because friends as competitors and drivers for advancement are not met. Previously, children studied with their friends to work together, encourage each other, compete to get good grades and obey school rules, and so on, but now, they have to learn individually. They lost the community, learning competition, and learning experience.

Online learning using technology allows children to use cellphones, tablets, and other gadgets, in which they were previously kept away and even prohibited from holding such devices except during school holidays with a certain time limit. Those gadgets make children unable to control themselves from playing games more than opening learning tools. Television programs also interfere with children's concentration at home learning. The change of learning system from offline to online has also altered children's learning rhythm from neatly structured to unstructured. It is because online learning can be done anytime and anywhere. It can be done in the morning, afternoon, evening, and night. It can also be done anywhere, such as at the dining table, in the living room, family room, bedroom, and house terrace. This makes children more relaxed and less focused on learning the materials sent by their teachers through WhatsApp group. All of these are the things that can distract children when studying at home. This is in line with what Ulum states, that there is an element of technology addiction among students, that has been misused outside the interests of learning due to the flexible rhythms [15].

The online learning system requires skills in applying technology during the learning process. Unfortunately, children's level of literacy towards information technology is still relatively low and requires parental assistance. The learning process that has been carried out so far depends on the presence of the teacher in class to provide detailed explanations of the various subjects that the students must take. Now this dependence has shifted to the availability of internet and technology as the media for online learning. Further, this shift in learning tradition has ensnared the teachers to position themselves more as subjects and children as objects who can only accept instructions and do assignments with certain deadlines [16]. Applications that are often needed by children as media of communication with teachers include Whatsapp group, Zoom, and Quiziz. Meanwhile, applications for finding information and material descriptions are Youtube, Google, browsers, and WPS. These numerous applications have multiplied the children's difficulties in the learning process during the pandemic situation. 


\subsection{Parents' Complaints and Difficulties}

Table 2: Parents' experiences as online learning companions

\begin{tabular}{|c|c|c|}
\hline No. & Parents' Experiences & Code \\
\hline 1 & $\begin{array}{l}\text { Lack of material } \\
\text { comprehension to teach my } \\
\text { children }\end{array}$ & $\begin{array}{l}\text { Not } \\
\text { professional }\end{array}$ \\
\hline 2 & $\begin{array}{l}\text { It is not possible to read all the } \\
\text { children's books in a short time } \\
\text { while the teacher does not } \\
\text { provide a summary of every } \\
\text { subject. }\end{array}$ & $\begin{array}{l}\text { Not } \\
\text { professional }\end{array}$ \\
\hline 3 & $\begin{array}{l}\text { If children still did not } \\
\text { understand, I asked the class } \\
\text { teacher or subject teacher with } \\
\text { the help of technology, but the } \\
\text { answer was difficult to } \\
\text { understand. }\end{array}$ & $\begin{array}{l}\text { Having } \\
\text { limitations }\end{array}$ \\
\hline 4 & $\begin{array}{l}\text { Children's school lessons are } \\
\text { now more complex }\end{array}$ & Complexity \\
\hline 5 & $\begin{array}{l}\text { I was unable to control } \\
\text { children to stay focused during } \\
\text { their study }\end{array}$ & $\begin{array}{l}\text { Having } \\
\text { limitations }\end{array}$ \\
\hline 6 & $\begin{array}{l}\text { Since online learning can be } \\
\text { done at any time, teacher } \\
\text { sometimes gives an evaluation } \\
\text { at } 19.00 \text {, which causes struggle } \\
\text { for children living in the } \\
\text { village. At that hour, the lights } \\
\text { are out and the wifi also turns } \\
\text { off, so they can not follow the } \\
\text { quiz shared by the teacher }\end{array}$ & $\begin{array}{l}\text { The loss of } \\
\text { opportunity }\end{array}$ \\
\hline 7 & $\begin{array}{l}\text { Sometimes, the quiz is shared } \\
\text { when the child is sleeping, and } \\
\text { to get a mark, the parents do } \\
\text { the quiz. }\end{array}$ & $\begin{array}{l}\text { Making } \\
\text { children } \\
\text { dependent }\end{array}$ \\
\hline 8 & $\begin{array}{l}\text { The delivery of materials and } \\
\text { learning process is not } \\
\text { optimum, so the evaluation } \\
\text { result is also not optimum }\end{array}$ & $\begin{array}{l}\text { Minimum } \\
\text { knowledge }\end{array}$ \\
\hline 9 & $\begin{array}{l}\text { It is difficult to condition } \\
\text { children because family } \\
\text { members are playing and } \\
\text { watching TV }\end{array}$ & $\begin{array}{l}\text { Not } \\
\text { conducive }\end{array}$ \\
\hline 10 & $\begin{array}{l}\text { Sometimes I was asked about } \\
\text { materials that I did not } \\
\text { understand }\end{array}$ & $\begin{array}{l}\text { Not } \\
\text { professional }\end{array}$ \\
\hline 11 & $\begin{array}{l}\text { I found difficulties when } \\
\text { children got craft assignments }\end{array}$ & $\begin{array}{l}\text { Not } \\
\text { professional }\end{array}$ \\
\hline 12 & $\begin{array}{l}\text { I found difficulties when } \\
\text { teaching art assignments }\end{array}$ & $\begin{array}{l}\text { Not } \\
\text { professional }\end{array}$ \\
\hline 13 & $\begin{array}{l}\text { I also have an online job, so I } \\
\text { do not focus on assisting } \\
\text { children's learning }\end{array}$ & Extra burden \\
\hline 14 & $\begin{array}{l}\text { I use Google when I have } \\
\text { difficulty in assisting them } \\
\text { studying. }\end{array}$ & $\begin{array}{l}\text { Technology } \\
\text { utilization }\end{array}$ \\
\hline
\end{tabular}

Parents are at the forefront in taking the main responsibility of the learning process carried out at home, while previously this was under the responsibility of school members, such as teachers, school principals, administrative staff, etc. This shift has brought about struggle and obstacles for parents, such as, first, they are required to master all subjects in formal education; second, they find it difficult to control their children to make sure they continue learning; third, they are not being able to support their children's learning optimally. These are shown in table 2.

The change in the learning system from school-based to home-based has shifted the role of learning assistance for elementary school children from teachers to parents. The involvement of parents in the full-time formal learning process, which had been the role of teachers at schools, causes obstacles and difficulties for them. The demand for comprehensive understanding of a variety of subjects that must be explained to children becomes a burden for parents. They are unable to learn all the materials that should be taught by professional teachers in their respective fields, while all online learning must be handled by parents. Along with that, the multiburdens carried by parents (mothers) in times of crisis by the Covid-19 pandemic have caused them depression and despondency, which impact their children. Furthermore, they are often unable to answer the questions raised by children about assignment. In other words, the professional role of teachers has not been able to be replaced by parents in a personal way during the learning process at home. This is supported by Wardani's research, which shows that in accompanying children's learning during this pandemic situation, parents have experienced obstacles such as media literacy, lack of infrastructure and opportunities, and problems in understanding materials [17].

Another obstacle faced by parents is their inability to control their children to stay concentrated on learning. This is due to the inconducive situations and conditions of learning at home. For example, when children are studying, at the same time, other family members are watching TV or doing other activities that can interfere with children's learning concentration. Learning at schools has uniform study time and break time, so children get conditioned to be discipline and focus on the learning process. Parents with their own characteristics are sometimes unable to prevent their children's whining and indulgence for refusing to continue studying. Another obstacle is the internet connection for those living in the suburbs. When teachers send exercises through Quiziz application with a 30-minute time limit of working, some of these residents are unable to finish it due to their limited internet access time and sometimes, because it is sent at that time the child is still sleeping. This makes parents unable to control, direct and condition their children to learn [18]. This is the most difficult obstacle that the parents face.

Many parents cannot provide maximum assistance to their children for studying at home due to three issues. First, parents also have their online work that needs to be completed immediately, so the time to accompany children to study coincides with their own working time. 
Second, parents (mothers) must also take care of other family members, all of whom need attention. Thus, the mother's attention is divided between teaching a child who is learning and taking care of other family members who need attention. Third, the domestic work of a mother that must be fulfilled every day is very timeconsuming that providing maximum assistance to the children's learning process is difficult. Therefore, the shift of the learning system from school-based to homebased becomes an additional burden for parents, especially for mothers [19].

\subsection{Impact of Online Learning on Education Purposes}

Lockdown and social distancing policies disarrayed national education's purposes and mission. All this time, educational purposes were contained in the learning curriculum in every educational stage, including elementary school curriculum. However, Covid-19 outbreak has ravaged the component structure of educational purposes such as character, cognitive, affective, and psychomotor educations, which have been neatly constructed in curriculum and learning process plan. Table 3 shows the purposes of education in Indonesia.

Table 3: Indonesia's Educational Purposes

\begin{tabular}{|c|c|c|}
\hline No. & Educational Purposes & Code \\
\hline 1 & $\begin{array}{l}\text { "Law Number } 20 \text { of } 2003 \text { about National Education System, Article } 3 \text {, the national } \\
\text { educational purpose is to develop student's potential to become human beings who } \\
\text { believe in the Almighty God, develop noble character, are healthy, knowledgeable, } \\
\text { capable, creative, independent, and become democratic and responsible citizens. }\end{array}$ & $\begin{array}{l}\text { Faithful and } \\
\text { virtuous }\end{array}$ \\
\hline 2 & $\begin{array}{l}\text { The national educational purposes are to develop Indonesian people and advance their } \\
\text { intellectual life. Thus, they can be people who have piety and faith to the Almighty } \\
\text { God, noble, independent, and firm personalities, excellent physical and mental health, } \\
\text { skills and knowledge, and last, sense of responsibility for the nation and society. }\end{array}$ & $\begin{array}{l}\text { Advancement } \\
\text { intellectual life }\end{array}$ \\
\hline 3 & $\begin{array}{l}\text { The national purpose which is contained in } 4^{\text {th }} \text { paragraph of The } 1945 \text { State Constitution } \\
\text { of the Republic of Indonesia Preamble states "... advance the intellectual life of the } \\
\text { people and..." }\end{array}$ & $\begin{array}{l}\text { Advancement of } \\
\text { intellectual life }\end{array}$ \\
\hline 4 & $\begin{array}{l}\text { Article } 28 \mathrm{C} \text { of the } 1945 \text { State Constitution of the Republic of Indonesia mentions that } \\
\text { every citizen has the right to develop themselves by fulfilling their basic needs, to } \\
\text { receive education, and to receive benefits from science and technology, art, and culture } \\
\text { for improving their life quality and community prosperity. }\end{array}$ & Quality \\
\hline 5 & $\begin{array}{l}\text { Law Number } 20 \text { of } 2003 \text { about National Education System in Article } 11 \text { paragraph (1) } \\
\text { determines that the central and regional governments must make service and facility } \\
\text { widely available and ensure the education implementation for every citizen without } \\
\text { discrimination. }\end{array}$ & Excellent value \\
\hline
\end{tabular}

The shift of education system from conventional to digital due to Covid-19 causes the lack of learning quality. Lessons are presented by teachers in the form of assignments without a comprehensive and profound explanation. Along with that, the knowledge and information learnt by students from every study material received become limited and have poor quality. Elementary students are forced to study independently, to find what they do not understand from their assignments by themselves. They have to find examples of dance movement, each note that should be played with melodica and others by themselves. According to developmental psychology, they still need teacher to guide, lead, direct and give explanation and concrete example of every material that they should learn. On the one hand, the Covid-19 pandemic creates an independent learning for children since early age, but on the other hand, there is a lack of quality of learning material that should have been received by students through learning experiences with teachers and friends at school.

Home learning process has eliminated motor learning which is a process to form a cognitive system related to students' movements. Motor learning is a major activity for elementary students that can facilitate their understanding of materials and internalization of values by practicing theory and lesson concepts directly in the field [20]. Online learning fully depends on mastering the material in the brain only, without manifesting it in behavior. Learning from home restricts the materials to be only theoretical, causing the children to be less perceptive and less intelligent in facing various problems. Online education is expected to transform a great amount of knowledge, but in contrast, it only moves the learning place from school to home and even erases a number of dimensions. As stated by E. Hanik, educational purpose is comprehensively directed to 
develop students' independency and liberal mentality and facilitate them to become humanistic and democratic. On the contrary, online learning only oppresses children with learning technology [16].

The Covid-19 outbreak causes a very low internalization of value from every learning material. Good habits that have been built together with the community so far, such as congregational prayer, Quran recitation, and collective Quran memorization listening between children, working together, and respecting differences have disappeared as the learning process is carried out at home. Learning at home is an opportunity to train children to be responsible, but many of them might become more pampered because there are people who help them tidying up their books, toys, shoes, bags etc. At school, children can be really independent and responsible of their own belongings because otherwise, there are several consequences like losing their belongings if they do not put them in the right place. Children also develop responsibility and independency with their friends, so they feel more comfortable and not forced. At home, children rely more on adults and people who are more capable than them, which cause dependency on other family members.

\section{CONCLUSION}

The result of this research shows that that online learning using technology during Covid-19 pandemic has reduced children' comprehension of knowledge. Explanation previously given by professional teacher is being replaced by technology which requires children to access the information they need independently. Meanwhile, mothers or parents are more of personal companions than professional, thus knowledge and materials that should be taught profoundly to children become less comprehensive. As a result, the purposes of education and learning written in the National Education Laws, curriculum, and every subject cannot be attained optimally.

This research also shows the emergence of new transformation in education sector as a result of the forced implementation of technology in education system. Elementary school students who are still highly dependent on other people, such as friends, teachers, and parents, are actually able to design their activities independently. They can adapt to technology literacy which enables them to access material and explanation.

This study is limited as it only examines elementary school students' perspectives and parents' role as learning companions in one city, so the result cannot provide a complete and broad picture of learning experience during the pandemic. Technology utilization that relies on signal availability has caused different level of accessibility in different places. Therefore, wider location and larger sample size are suggested for future research so that the learning experiences observed are more varied and able to support the data and information for establishing education policy that accommodate every level of education.

\section{REFERENCES}

[1] D. S. W. Ting, L. Carin, V. Dzau, and T. Y. Wong, "Digital technology and COVID-19," Nature Medicine. 2020.

[2] H. Budiman, "Peran Teknologi Informasi Dan Komunikasi Dalam Pendidikan," Al-Tadzkiyyah J. Pendidik. Islam, 2017.

[3] S. Z. Mohid, R. Ramli, K. A. Rahman, and N. N. Shahabudin, "Teknologi multimedia dalam pendidikan abad 21," Int. Res. Manag. Innov. Conf., 2018.

[4] M. Ngafifi, "Advances in Technology and Patterns of Human Life in Socio-Cultural Perspective," J. Pembang. Pendidik. Fondasi dan Apl., 2014.

[5] F. Z. Adami and C. Budihartanti, "Penerapan Teknologi Augmented Reality Pada Media Pembelajaran Sistem Pencernaan Berbasis Android," Tek. Komput. AMIK BSI, 2016.

[6] M. Ramli, "Aplikasi Teknologi Multimedia Dalam Pendidikan," Ittihad J. Kopertais Wil. XI Kalimantan, 2013.

[7] L. Sudibyo, P. Universitas, V. Bangun, N. Jl, and L. Sujono, "Peranan dan Dampak Teknologi Informasi dalam Dunia Pendidikan di Indonesia," Widyatama, 2011.

[8] E. Y. Wijaya, D. A. Sudjimat, and A. Nyoto, "Transformasi Pendidikan Abad 21 Sebagai Tuntutan Pengembangan Sumber Daya Manusia di Era Global," J. Pendidik., 2016.

[9] S. Kusmana, "Pengembangan Literasi Dalam Kurikulum Pendidikan Dasar Dan Menengah," $J$. Pendidikan, Kebahasaan, dan Kesusastraan Indones., 2017.

[10] A. Purnomo, H. Hartatik, I. J. Cahyaningsih, R. Hartono, and S. A. Tri Bawono, "Pengembangan Aplikasi E-Learning Sekolah Menengah ATAS," Simetris J. Tek. Mesin, Elektro dan Ilmu Komput., 2017.

[11] Syamsuar and Reflianto, "Pendidikan Dan Tantangan Pembelajaran Berbasis Teknologi Informasi Di Era Revolusi Industri 4.0," Pendidik. Dan Tantangan Pembelajaran Berbas. Teknol. Inf. Di Era Revolusi Ind. 4.0, 2018. 
[12] M. A. Ghufron, "Revolusi industri 4.0: Tantangan, Peluang dan Solusi Bagi Dunia Pendidikan," Semin. Nas. dan Disk. Panel Multidisiplin Has. Penelit. dan Pengabdi. Kpd. Masy., 2018.

[13] Mukminan, "Tantangan Pendidikan di Abad 21," Teknologi Pendidikan, 2014.

[14] D. Bouhnik and G. Carmi, "E-learning environments in academy: Technology, pedagogy and thinking dispositions," J. Inf. Technol. Educ., 2012.

[15] M. S. Ulum and J. Pamungkas, "Analisis Kritis Penerapan Metode Pembelajaran Berbasis Online Di Madrasah Ibtidaiyah Masa Pandemi Covid 19 (Solusi Menyelamatkan Masa Depan Anak-Anak Indonesia)," MUBTADI J. Pendidik. Ibtidaiyah, 2020.

[16] E. U. Hanik, "Self Directed Learning Berbasis Literasi Digital Pada Masa Pandemi Covid-19 Di Madrasah Ibtidaiyah," Elem. Islam. Teach. J., 2020.
[17] A. Wardani and Y. Ayriza, "Analisis Kendala Orang Tua dalam Mendampingi Anak Belajar di Rumah Pada Masa Pandemi Covid-19," J. Obs. J. Pendidik. Anak Usia Dini, 2020.

[18] A. F. Sabiq, "Persepsi Orang Tua Siswa tentang Kegiatan Belajar di Rumah sebagai Dampak Penyebaran Covid 19," Ilmu Pendidik. Pkn dan Sos. Budaya, 2020.

[19] R. Handayani, "Multi Peran Wanita Karir Pada Masa Pandemi Covid-19," J. Kaji. Gend. dan Anak, 2020.

[20] T. Murti, "Perkembangan Fisik Motorik dan Perseptual Serta Implikasinya pada Pembelajaran di Sekolah Dasar," Wahana Sekol. Dasar, 2018. 